\title{
«ДЕРЖАВНИЙ» VS «НАЦІОНАЛЬНИЙ»: ЕВОЛЮЦЯ КЛАСИЧНОГО УНІВЕРСИТЕТУ У «ДОВГОМУ» ХІХ СТОЛІТТІ
}

\author{
C. I. Посохов
}

Посохов С. I. «Державний» vs «національний»: еволюція класичного університету у «довгому» XIX столітті. У статті йдеться про процеси націоналізації, які охопили класичні університети Європи у XIX - на початку XX ст. Зазначається, що університети значною мірою сприяли такого роду процесам, але в підсумку це обумовило загострення протиріччя між імперським призначенням та регіональними функціями університетів, спричинило кризу університетської ідентичності, а під час Першої світової війни та пізніше призвело до суттєвих змін в устрої самої моделі класичного університету.

Ключові слова: класичний університет; націоналізація освіти; університетська ідентичність.

Посохов С. И. «Государственный» vs «национальный»: эволюция классического университета в «долгом» XIX веке. В статье говорится о процессах национализации, которые охватили классические университеты Европы в XIX - начале XX в. Отмечается, что университеты в значительной мере способствовали такого рода процессам, но в итоге это обусловило обострение противоречия между имперским назначением и региональными функциями университетов, вызвало кризис университетской идентичности, а во время Первой мировой войны и позже привело к существенным изменениям в устройстве самой модели классического университета.

Ключевые слова: классический университет; национализация образования; университетская идентичность.

Posokhov S. I. "State" vs. "National": the Evolution of the Classical University in the "Long" $19^{\text {th }}$ Century. The author depicts the processes of nationalization that covered classical European universities in the $19^{\text {th }}$ - early $20^{\text {th }}$ centuries. The universities contributed significantly to this kind of processes, but as a result, this led to an aggravation of the contradiction between the imperial appointment and the regional functions of universities, caused a crisis of university identity, and during the First World War and later led to significant changes in the structure of the model of the classical university.

Keywords: classical university; nationalization of education; university identity.

Коли виник перший університет? Як це сталося? Коли сформувалися його основні характеристики? Університетська історія - довга. Вважається, що через нетривалий час університету як явищу світової культури виповниться тисячу років. В енциклопедіях зазвичай зазначається, що найстарішим у Європі є Болонський університет, який виник у 1088 році. Але довести це неможливо (у історичному документі йдеться про «болонські школи»). Дату заснування (1088 р.) у XIX ст. вигадав італійський поет і літератор Д. Кардуччі, аби відсвяткувати 800 -річчя цього університету. За 1000 років університет не стояв на місці, відповідно, ми можемо казати про різні типи, моделі. На сьогодні утвердилася типологія німецького дослідника Петера Морава ${ }^{1}$. Він запропонував виокремлювати три типи: середньовічний (докласичний), класичний та посткласичний університети.

Декілька слів про докласичний (середньовічний) університет. Його ще називають церковний або корпоративний. Я не буду надавати загальну характеристику цьому університету, лише зазначу, що це був наднаціональний заклад. Тривалий час мовою викладання була латина (основа для навчання представників різних країн), функціонування університетів відбувалося в межах єдиного католицького світу. Зокрема, серед найважливіших привілеїв було отримання учених ступенів. Цей привілей гарантувався Папою Римським й надавав можливість реалізовувати його на території підвладного йому християнського світу.

Втім, як відомо, у XVI ст. у Європі почалася Реформація й тоді ж розпочався поділ університетів за конфесійною ознакою на католицькі та протестантські. Цей період на- 
зивають періодом територіально-конфесійних університетів (або т. зв. «пізньоуніверситетський період», який тривав з XVI до XVIII ст.). У цей період виникло багато університетів, часто у невеликих містах та містечках Західної Свропи (особливо у німецьких землях: вони засновувалися як місцевими князями, так і місцевою духовною владою архієпископами). Цей процес конфесіоналізації освіти охопив і Східну Європу. Зокрема, були створені «Академія та університет Віленський товариства Ісуса» (1579), протестантська Академія Густавіана в Дерпті (1632), Львівський єзуїтський колегіум (1608), який у 1661 р. спробували перетворити на університет. Сьогодні дослідники небезпідставно ведуть мову й про православний університет (Києво-Могилянська академія, Московська слов'яно-греко-латинська академія).

XVI-XVII століття стали періодом не лише конфесіоналізації освіти, а й кривавих конфесійних війн. Як відомо, у 1555 р. був укладений Аугсбургский мир. Він передбачав право володарів у межах Священної Римської імперії на вибір релігії. Тоді як піддані такого права не мали. Виник принцип: чия влада, того ж і віра («сujus regio, eius religio»). Відповідно, це позначилося й на університетах, де панував теологічний факультет. Зміна віри володаря часто призводила до того, що відбувалася повна заміна професорів (поставала дилема: або зміна конфесійної належності, або еміграція). У цей час в житті університетів підвищується роль місцевих князів, внаслідок секуляризації деякі університети отримали монастирські та церковні будинки і землі. Однак міжконфесійна ворожнеча на цьому не припинилася. Лише Вестфальський мир (1648), який знаменував завершення Тридцятилітньої війни, утвердив принцип свободи віросповідання, віротерпимості. Саме 3 цього часу дослідники кажуть про систему національних держав, про громадянський націоналізм (приналежність людини до нації визначалася добровільним особистим вибором й ототожнювалася з громадянством).

Поступово такі принципи утвердяться і в університетах. Відбувається посилення світського начала, зменшується значення теологічного факультету. Вперше принцип віротерпимості був запроваджений у новоствореному університеті в Галле (1699) й це знаменувало початок нової доби в історії європейських університетів. У XVIII ст. поступово відбувається перехід на викладання національними мовами. Але такий крок був пов'язаний не стільки з виникненням націоналізму і десакралізацією латини, скільки 3 намаганнями централізувати державу. Держава в період освіченого абсолютизму була зацікавлена в «уніфікації» мешканців на своїй території, перетворення їх з носіїв конфесійної чи регіональної ідентичності на універсальну категорію «підданих» - «державну націю», а освіту використовували як інструмент для досягнення цієї метиㄴ․ Саме так, як засіб централізації та комунікації народів імперії, розглядав німецьку мову австрійський імператор Йосип II, який 1784 р. видав відповідний наказ. Як відомо, саме у цей час був заснований і Львівський університет як німецький (і називався він «Йосифінський»)*. Наперед зазначу, що з цього часу почне розгортатися боротьба за двомовність (утраквізацію) в освіті. Потужним поштовхом для цього процесу стане революція 1848 p.

Але, повертаючись до загальної університетської історії, зазначу, що у XVII-XVIII ст. спостерігається криза університетів. Саме у цей час виникли так звані «сімейні університети», спостерігається торгівля дипломами, розповсюдженим явищем стає пияцтво студентів... Доба просвітництва (XVIII ст.) - ворожа до університетів. I йдеться не лише про глузування з боку інтелектуалів. За критикою почалися й дії: за період з 1789 до 1815 p. кількість університетів у Європі скоротилася вдвічі - 3143 до 83. У Франції 1792 р. всі університети були закриті. У Німеччині під впливом французьких подій та наполеонівських війн також було ліквідовано декілька університетів (із відомих: Кьольнський у 1794 р., Ерфуртський у 1816 р., а також Віттенберзький, Майнцьський та ін.) ${ }^{* *}$.

\footnotetext{
* У 1773 р., після розпуску Ордену єзуїтів, був зліквідований й підпорядкований йому Львівський колегіум. У 1805-1818 pр. університет був перетворений на ліцей. У 1817 р. університет було відновлено (називався Університет Франца I). Він залишався німецьким, але у 1822 р. поляки домоглися заснування у ньому кафедри польської мови й літератури.

** Зауважимо, що завдяки цьому деякі іноземні професори прибули до новоствореного Харківського університету (1804).
} 
Водночас у XVIII ст. університет став на шлях модернізації: відбулося його перетворення $з$ корпорації на державну установу (тому цей університет також називають «державним»). Втім, також називають «класичним», «дослідницьким», «гумбольдтівським». Зазвичай, початок позначають так: «близько 1800 р.» і пов'язують із створенням Берлінського університету (1809/1810 р.) та іменем Вільгельма фон Гумбольдта (тому іноді кажуть про «модель Гумбольдта»). Цей тип університету виник на основі філософії неогуманізму. Так, відповідно до загальної концепції Гумбольдта, оновлений німецький університет мав бути не спеціалізованим навчальним закладом, а тим місцем, де відбувався процес «більдунга» (самовдосконалення). Він повинен був стати вершиною піраміди національної освіти. Основними принципами «класичного» («гумбольдтівського») університету стали такі: академічні свободи «викладання та вчення»; єдність викладання та дослідження («не учитель для учня, але обидва для науки»); професори перебувають на службі у держави, але зберігається університетське самоуправління.

До розробки таких принципів долучилися й інші мислителі, зокрема, Фрідріх Шлейермахер, Фрідріх Шиллер, Йоганн Фіхте, Генрік Штеффенс. Дехто сьогодні каже про «гумбольдтівський міф»³. I справа тут не тільки в тому, що такі ідеї висловлював не лише В. Гумбольдт. Справа в тому, що у чистому вигляді такого університету не було. Більше того, деякі риси цього типу можна віднайти раніше (до заснування Берлінського університету). Так, наприклад, куратор Гетінгенського університету барон Герлах Адольф фон Мюнхгаузен (1688-1770) вперше чітко висловив думку, що держава сама має вирішувати в чому полягають обов'язки і норми поведінки професорів. Професорам, які були позбавлені корпоративних зобов'язань між собою, повсякчас нагадували, що вони є державними службовцями і мають служити одній лише науці. Тобто, при заснуванні Берлінського університету відбулася свого роду «кристалізація» реформ. Саме тому інколи гумбольдтівський університет також називають модерний університет ${ }^{4}$.

Серед перших, заснованих на зазначених принципах у XIX ст., були Боннський (1818) та Мюнхенський (1826) університети. Австрійські університети лише після революції 1848 р. набули нових ознак. Російські університети на початку XIX ст. створювалися як модерні (відповідно, можемо казати, що Харківський - перший модерний університет на українських землях). Звичайно, й на цьому етапі спостерігаються регіональні особливості університетів. Дехто виокремлює чергові типи чи моделі: французька модель «великих шкіл» (максимум одержавлення, акцент на спеціалізованій освіті та нормативному знанні), англійська (збереження багатьох рис корпоративного університету, увага вихованню), німецька (державний, але з певною автономією, поєднання загальнонаукового та спеціального). Вже ідеологи німецького класичного університету зрозуміли, що залежність від держави загрожувала самостійності думок в університетах, саме тому вони наполягали: держава не повинна керувати університетами, а лише піклуватися про них. Втім, на практиці, в багатьох країнах процес одержавлення підім'яв університетські свободи (типовими в цьому плані стали Франція та Росія).

Тепер перейдемо до питання, яка заявлено у назві статті - «класичний університет та процес становлення модерних націй». Класичний університет, серед іншого, називають «національним». Хоча, взагалі, на початковому етапі його розвитку здебільшого мова йшла про роль держави. Симптоматично, що у двох засадничих працях В. Гумбольдта и Ф. Шлеєрмахера (які наведені у додатку до антології «Університетська ідея в Росії» 5 ) термін «держава» та похідні слова згадано більше 80 разів, а «націю» та похідні лише 5. Менше $з$ тим вже у першому абзаці своєї праці «Про внутрішню та зовнішню організацію вищих наукових закладів в Берліні» (1809) В. фон Гумбольдт визначає університет як «вершину, в якій сходиться все те, що безпосередньо відбувається для духовного зростання нації». Почасти це пояснюється засадничою роллю для В. Гумбольдта (і зростаючого покоління романтиків) поняття «дух нації». Вважається, що реформа освіти, яку здійснив Гумбольдт, сприяла відродженню Пруссії, а потім і всієї Німеччини після кризи, спричиненої наполеонівськими війнами. 3 часом німецька університетська освіта стала світовим стандартом. Втім, дехто пов'язує специфіку цієї моделі саме з особливостями німецької культури, менталітету, способу мислення («народ мислителів та поетів»).

Почасти так думали й самі німецькі професори. I все ж, тривалий час панувала думка про те, що університет скоріше є наднаціональним закладом, висловлювалися 
застереження проти захоплення національним. Зокрема, професор Берлінського університету Фрідріх Паульсен (1846-1908) у своїй відомій книзі «Германські університети», яка вийшла друком наприкінці XIX ст. (російський переклад 1904 р.), зазначав: «Но такой задачи [виховувати патріотизм. - C.П.] ... университет взять на себя не может. Он не является воспитательным учреждением, а студенты не дети. Университет - учреждение для научного исследования и научного преподавания, которое он предоставляет без всякого различия как своим соотечественникам, так и иностранцам. Поскольку он исследует духовную сущность немецкого народа и углубляет понимание его исторической жизни, можно быть уверенным, что университет пробуждает привязанность и любовь к Германии и, быть может, даже облегчает те тяжелые впечатления, которые можно было бы вынести из современного положения вещей. И это равно применимо и к немцам, и к иностранцам, посещающим немецкие университеты. ... Университеты никогда не должны забывать, что блага, о которых они призваны заботиться, не знают национальных и территориальных границ: истина и наука, по самой их природе, представляют блага всего человечества, так как они создаются сотрудничеством всех народов, принимающих участие в духовной жизни человечества. Люди, находящиеся на службе у науки, образуют нечто в роде франкмассонского союза, как его понимал Лессинг: не связанные тем, что разделяет нации, религии и сословия, они имеют только одно призвание: представлять общечеловеческое и защищать его против узких, частных стремлений. Мы теперь еще яснее, чем в эпоху Лессинга, чувствуем, что всеобщее может иметь конкретную жизнь только в особенном, что богатство человечества покоится на разнообразии национальных особенностей. Но мы не забудем также прекрасных слов Лессинга, что есть пределы, за которыми патриотизм так же, как и конфессионализм, перестает быть добродетелью. Чрезмерный национализм стал серьезной опасностью для всех европейских народов; они рискуют потерять понимание всего общечеловеческого. Доведенный до крайности национализм точно также, как и конфессионализм, убивает совесть и даже логическую последовательность мышления: понятия о справедливом и несправедливом, о хорошем и плохом, об истинном и ложном теряют всякое значение; то самое, что считается позорным и недостойным человека, когда это делается другими, рекомендуется своему же народу, как оружие против чужой нации»

Однак, таке розуміння університету наштовхнулося на інші реалії другої половини XIX - початку XX ст. Як відомо, вже у середині XIX ст. націоналізм став впливовим політичним феноменом, а у другій половині XIX ст., 3 початком ери «масової політики», перетворився на глобальну силу․․ Університети не лише сприяли цьому процесу, а й опинилися на його вістрі.

Зокрема, університети зробили величезний внесок у справу збирання та популяризації культурного спадку у тих регіонах, де вони функціонували, у розвиток національної ідентичності тих народів, які були в межах їх досяжності, a, з часом, перетворилися й на осередки національного руху (чимало активістів національних рухів вийшли саме 3 університетського середовища). Г. Касьянов, скажімо, в цілому визначив характер українського націоналізму кінця XIX - початку XX ст. як «інтелігентський». Далеко ходити не треба: приклади надає історія Харківського університету. На думку В. Г. Сарбея, Харківський університет «став не лише науково-освітнім центром, а й охоронцем та провідником української культури» ${ }^{8}$.

Втім, університети не лише сприяли розвитку певних національних культур, але й відчували на собі їх вплив. Більше того, в деяких випадках вони ставали свого роду «яблуком розбрату». Як відомо, утвердження єдиної «мови високої культури» стало загальною тенденцією розвитку націй-держав у Свропі того часу․․ Але ця тенденція протистояла намаганням інших етносів, відстоювати свою мовну та культурну самобутність. Сучасна німецька дослідниця історії університетів Труде Маурер зазначає: «...В областях со смешанным населением, при неопределенной или разноориентированной политической и культурной принадлежности его групп, университеты рассматривались любой из сторон как своего рода бастионы или форпосты в борьбе за гегемонию» ${ }^{10}$. Ця дослідниця першою також відзначила протиріччя, яка подекуди виникало між імперським призначенням та регіональними функціями університетів. 
Зокрема, воно дуже гостро постало в Австрійській (Австро-Угорській імперії)*. Приклад цьому надає історія Карлова університету в Празі, який став каменем спотикання між німцями та чехами ${ }^{11}$. Зрештою решт, у 1882 р. він був поділений на німецький та чеський (при цьому обидва називалися «Карлів університет»). Студенти заходили до будівлі в різні двері та навчалися окремо. Професори кидали жереб стосовно того, який $з$ двох університетів буде використовувати актову залу у парні, а який у непарні дні. У 1891/92 н. р. розділ торкнувся й богословського факультету. Першими розмежування відбулося на рівні студентських об'єднань, а потім - й серед професури. Зрозуміло, що попереду у таких баталіях йшли філологи та історики. Філологи дискутували про те, чи стала чеська мова мовою науки. Що ж стосується історії, то ідейні супротивники актуалізували питання про призначення університету в момент його заснування. Зокрема, сперечалися з приводу того, чи засновував університет Карл IV як король Богемії, чи як германський імператор (тобто - як земельний навчальний заклад чи імперський?). 3 часом, почали лунати не тільки мовні вимоги, а й політичні звинувачення. Так, у Празі деяких німецьких професорів зараховували до «прусської партії» за наявність «великогерманського стану думок» і тим самим фіксували їх «неавстрійськість».

Складні стосунки у професорсько-викладацькому середовищі ілюструє наступний факт, який наводить Т. Маурер. Історик та архіваріус Богемського архіву Антонін Гінделі (походив від змішаного шлюбу), який читав лекції як німецькою, так і чеською, і який у 1880 р. підписав петицію чеських викладачів, у тому ж році був звинувачений чехами за свою «європейську позицію» у викладенні історії тридцятирічної війни. Він вважав себе в першу чергу австрійцем і при розділі університетів залишився в німецькому. Втім, невдовзі йому довелося відбиватися від підозр в тому, що він не в тому дусі читає лекції з історії Австрії...

Викладачі одного університету не працювали в іншому (хоча формально це допускалося). Навіть наукова дискусія між ними мала місце лише в письмовій формі, або на конференціях за кордоном. Фрідріх Йодль, який викладав філософію в Празькому університеті, писав наприкінці цього року своєму другу в Німеччину: «Чехов и немцев разделяет совершенно непреодолимая стена: прежде всего самих немецких из немцев, профессоров немецкого университета. Некоторых из нас, тех, кто раньше любезничал с чехами, а теперь остался у нас, полностью избегают. Вначале это кажется странным; однако когда понаблюдаешь некоторое время за развитием событий, то понимаешь, что это единственный способ предотвратить постоянные конфликты» ${ }^{12}$.

Місце традиційного університетського лібералізму зайняв радикалізм. У 1897 року в Празі відбулися студентські виступи проти німецького університету. Деякі професори не виходили 3 дому декілька днів. Натомість, у 1907 р. пролунало гасло «Німецькі студенти - в Прагу!», звісно, для того, щоби змінити співвідношення сил... Публічні лекції і курси цих двох університетів відбувалися з орієнтацією на різні міські громади... Тоді ж почали розробляти плани будівництва окремих університетів, розділення бібліотеки, щоби студенти могли «із задоволенням вчитися», оскільки вони будуть оточені лише своїми земляками**.

Подібні історії можна було спостерігати й в інших університетах. Так, щось подібне відбувалося у французькому Гентському університеті, який розташовувався у фламандській частині Бельгії. Та й, навіть, у Харківському університеті, оскільки тут на початку XX ст. серед професури виразно позначилися табори консерваторів-монар-

\footnotetext{
* Австро-Угорщину називали «клаптиковою» (рос. - «лоскутной») імперією, натякаючи на строкатість її національного складу (за даними перепису 1910 року: австрійці - 23,5\%, угорці - 19,1\%, чехи і словаки $-16,5 \%$, серби і хорвати $-10,5 \%$, поляки $-10 \%$, русини $-8 \%$, румуни $-6,5 \%$, словенці - 2,5\%, інші - 3,4\%). Російська імперія була не менше «клаптиковою».

** Під час окупації Чехословаччини нацистською Німеччиною в листопаді 1939 р. Чеський університет був закритий, а багато його студентів і професорів відправили до концтаборів. Після закінчення німецької окупації почалася депортація німецькомовного населення міста і, відповідно, німецький потік в університеті був закритий. У жовтні 1945 р. указом президента Е. Бенеша Німецький університет в Празі був закритий, а Чеський було відновлено як єдиний Карлов університет.
} 
хістів / російських націоналістів та «українофілів»". І хоча більшість професорів були схильні до лібералізму, національне протистояння в університеті поступово посилювалося. Втім, вочевидь, в українському національному русі першочерговою була роль

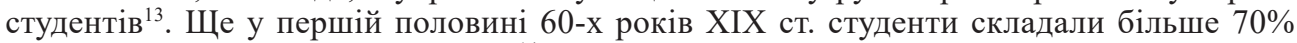
активістів українофільського руху ${ }^{14}$. Університети у Харкові та Києві при відсутності таких на території Білорусії - не менш важлива причина якісних відмінностей національного руху в Україні15.

Наприкінці XIX ст. національний рух в Україні набуває більш організованого характеру, спостерігається посилення його політичної спрямованості. У березні 1897 р. 3 ініціативи студента історико-філологічного факультету Д. Антоновича, студента фізико-математичного факультету М. Русова та студентів-технологів була створена Харківська українська студентська громада. У цей час спостерігаються виразні тенденції до радикалізації українського студентського руху. Зокрема, як відомо, вже названі студенти Харківського університету М. Русов та Д. Антонович стали ініціаторами й організаторами першої національної політичної партії Наддніпрянщини - Революційної української партії ${ }^{16}$.

Втім, більш характерною в цьому плані є історія Львівського університету. У ньому як уже зазначалося лекції читали переважно німецькою мовою, а з 1879 р. - польською**. Водночас, як відомо, в 1894 р. тут було відкрито кафедру всесвітньої історії з особливим оглядом історії Східної Європи і «руською» мовою викладання, яку посів М. Грушевський ${ }^{17} .31900$ р. у цьому університеті розпочали викладати українську мову та історію української літератури. Однак, це не задовольняло українське студентство, яке почало активно боротися за свої національні права. Як приклад, можна назвати сецесію українських студентів 1901-1902 рр. Це була реакція на рішення університетської влади виключити організаторів українських демонстрацій. Був створений спеціальний «Сецесійний фонд» для продовження студій в австрійських університетах поза Галичиною. У сецесії взяли участь 440 студентів. 3 цього часу набуває популярності ідея окремого українського університету ${ }^{18}$ або поділу Львівського університету на два - український та польський. Зокрема, у Львові в 1910 р. відбулися масові виступи з вимогою створення власне «українського університету» і сутички українських і польських студентів. Внаслідок цього питання про створення такого університету обговорювалося в австрійському парламенті. Тоді був розроблений проект імператорського рескрипту, відповідно до якого цей університет мали створити через десять років - в 1921-му році. Однак здійсненню цього наміру завадила Перша світова війна.

Ідея окремого українського університету базувалася на тому переконанні, що всі існуючі на українських землях середні і вищі школи призначені для «чужинців» і обслуговують їх інтереси ${ }^{19}$. Звичайно, такої позиції дотримувалися не всі українські інтелектуали. Так, М. П. Драгоманов писав про те, що «наука - світова річ; чужа нам буде наука тільки тоді, коли ми іiі не знаємо, а другі народи знають», але при цьому важливим кроком він вважав освоєння «чужої науки» рідною мовою ${ }^{20}$. М. С. Грушевський бачив завдання українських університетів в тому, щоб вони стали «живими органами, які чутливі до наукових потреб та культурних запитів місцевого суспільства» ${ }^{21}$. Важливо підкреслити, що на початку XX ст. позначилося певний рух «українських» університетів до формування свого національного обличчя, а також назустріч один до одного. На початку XX ст. активізувалися контакти представників «українських» університетів двох імперій. Це стосувалося як студентства, так і професорів. Наприклад, в 1906 р. почесними докторами Харківського університету було обрано М. Грушевського і І. Франко. Й хоча суто інституційні перешкоди тоді подолати було неможливо, однак, завдяки цьому, поступово формувалося уявлення про загальний культурно-історичний простір.

\footnotetext{
* В Харківському університеті проф. М. Ф. Сумцов першим у Російській імперії розпочав читання університетських лекцій українською мовою. Перша така лекція з української народної словесності відбулася 28 вересня 1907 р.

** 31867 р., коли було прийнято закон про мову навчання та роль у цьому процесі місцевих громад, у школах Галичини обов'язковим стало вивчення польської мови.
} 
Втім процеси націоналізації стимулювалися не лише «знизу», а й «згори». Наприкінці XIX ст. держава намагалася ефективніше використовувати університети з метою підпорядкування певних територій. Саме це дозволило Т. Мауреру використати таку метафору як «форпост» для позначення ролі університетів на культурному та політичному порубіжжі. Зокрема, такими університетами-форпостами вона називає Страсбурзький та Дерптський університети.

Страсбурзький університет був заснований в анексованому Німеччиною регіоні (Ельзас) й підкорявся не міністерству освіти, а напряму рейхсканцлеру. Він був добре оснащений, задумувався як зразковий. Викладачі розуміли свої зобов'язання перед новоствореною державою й сприймали його як «національну місію» 22.

Дерптський університет, як відомо, у XIX - на початку XX ст. функціонував у Російській імперії. Тривалий час він мав свою специфіку. Фактично це був німецький університет (і за мовою викладання, і за устроєм, і за складом викладачів та студентів). Він відігравав важливу роль для всієї імперської системи освіти (тут діяв Професорський інститут за часів Миколи I для підготовки викладачів для решти російських університетів). Втім, наприкінці XIX ст. почнеться його русифікація: на 1900 р. 3/4 складу викладачів становили росіяни, було надано дозвіл навчатися тут випускникам духовних семінарій (таке дозволялося лише у Томську та Варшаві). Російська мова стала панівною (німецькою викладали лише на теологічному факультеті, але й це 1916 р. було заборонено). Врешті відбулося перейменування: тепер це був Юр'євський університет.

Менше з тим, на початку XX ст., і в тому, і в іншому з названих університетів частина студентів та викладачів представляла, відповідно, французьку та німецьку спільноти. Зазвичай, кожна з них жила своїм життям. Так, професори зустрічалися лише на офіційних засіданнях. Студенти створили свої національні корпорації.

«Українські» університети цього часу, як відомо, перебували в різних державних системах, мали периферійне (а то й відверто «прикордонне») становище у відповідних державах, їхні професори були представниками різних націй, відчували на собі суттєвий вплив тих соціальних і культурних процесів, які відбувалися на цих територіях. У даному разі, кожен з цих університетів може розглядатися як «форпост». Втім, при більш пильній увазі, ми з'ясуємо, що картина суперечностей у цих університетах часто була більш строкатою, ніж у названих вище «університетах-форпостах».

Так або інакше, але головна тенденція полягала в тому, що модель національно замкнених навчальних закладів брала гору над двонаціональними або навіть наднаціональними навчальними закладами ${ }^{23}$.

Межею, яка відокремлює другий («класичний університет») та третій («посткласичний», або «масовий університет») етапи називають середину XX ст." Тим часом, початок кризи «класичного» університету дослідники визначають ще кінцем XIX - початком $\mathrm{XX}$ ст. $^{24}$ Свою роль в цьому процесі зіграла Перша світова війна, яка створила екстремальні зовнішні умови для науки і освіти, а також зумовила загострення внутрішніх конфліктів і суттєві зміни в самій університетській моделі ${ }^{25}$.

В тому числі Перша світова війна ще більше загострила напругу між регіональними функціями й імперським призначенням університетів, поглибила «розломи», які були в університетських корпораціях. Втім, на початковому етапі війни, в «патріотичному пориві» всі університети одностайно підтримали «свої» держави. 3 початком Першої світової війни в підтримці уряду на деякий час навіть об’єдналися університетські ліберали і консерватори. Про це свідчать відозви, які приймалися університетами всіх країн, залучених в конфлікт. Як зазначив О. М. Дмитрієв, вже ідея зв'язку справи вченого з долею його батьківщини (в елітарної-консервативному німецькому або цивільному французькому смисловому вживанні) призвела до уявленням про своєрідну «мобілізації інтелекту». Влітку і восени 1914 р. жанр відозви не тільки набув поширення в сфері зовнішньополітичної, але і позначив найбільш яскраво крах колишніх форм та ідеалів міжнародного наукового співробітництва ${ }^{26}$. На думку того ж О. М. Дмитрієва, ці мотиви «войовничого патріотизму»

\footnotetext{
* Зазвичай межею вважається утвердження в Німеччині нацистської диктатури в 1933 р.
} 
могли бути різними: від підтримки держави як носія і гаранта вищих духовних орієнтирів (мандаринська ідеологія в Німеччині), забезпечення державної єдності (тема, яка була актуальною для Австро-Угорщини) до захисту республікансько-демократичних завоювань від прусського мілітаризму (Франція та США), набуття неможливої раніше єдності з владою, народом і передовими демократіями Заходу (Росія, в останньому аспекті також Італія $)^{27}$. Незабаром такі виступи набудуть характеру очевидної пропаганди. Навіть вже після закінчення війни такі ідеологічні конструкції продовжували жити серед університетської спільноти, перешкоджаючи налагодженню інтернаціональних наукових зв'язків. Насіння недовіри, а потім і відчуження, проросли і дали рясні сходи.

Разом $з$ тим війна була пов'язана не тільки з «дебатами» і різноманітними словесними «поривами патріотизму». За словами пішли дії, які відбилися і на університетах. 3 початком військових дій відразу ж постало питання про перебування підданих ворожих держав в університетах тих чи інших країн. Деякі вчені, перебуваючи у закордонному відрядженні (в країні супротивника), були там інтерновані і відчували значні матеріальні труднощі. Потім розпочалося звільнення з університетів співробітників відповідної національності при найменшій підозрі в співчутті до «своїх» і бойкот наукової продукції «супротивника». Навіть в США, які до квітня 1917 р. офіційно не вступали у війну, вже починаючи з 1915 р. усувалися з посад викладачі німецької національності, які були запідозрені в прогерманській орієнтації ${ }^{2}$. У Росії 31 жовтня 1914 року Рада міністрів прийняла постанову «Про виключення підданих воюючих з Росією держав зі складу спілок, товариств та інших громадських і урядових організацій...». У запалі войовничих настроїв, а також керуючись секретним циркуляром Міністерства народної освіти від 26 листопада 1914 р. про виключення з числа почесних членів всіх «ворожих підданих», в 1915 р. Рада Харківського університету позбавила звання «почесних членів» кількох німецьких вчених ${ }^{29}$. Втім, ще у вересні 1914 р. відбулася публічна відмова 30 німецьких вчених від почесних звань «ворожих» університетів.

Як відомо, в 1914 р. в Києві був заарештований за звинуваченням в австрофільстві і відправлений на заслання до Симбірську М. С. Грушевський. У березні 1916 р. його ж позбавили посади професора Рада Львівського університету, на якій він перебував з 1894p. (у 1915 р. в польській публіцистиці було висловлено чимало суто ідеологічних звинувачень на його адресу $)^{30}$.

3 другої половини липня 1914 р. в Російській імперії була припинена виписка книг 3 Німеччини та Австро-Угорщини. 3 осені 1914 р. німецьку мову було заборонено використовувати в громадських місцях (16 червня 1915 р. за це був оштрафований професор Харківського університету А. Г. Зоммер), пролунали заклики не друкувати наукових праць німецькою мовою і в німецьких виданнях, припинити закупівлю в Німеччині наукових приладів і реактивів ${ }^{31}$. Бойкот німецької науки став початком процесу втрати тих пріоритетних позицій, які були досягнуті Німеччиною (і німецькою мовою як засобом наукової комунікації) на межі XIX-XX ст. Одночасно, це обернулося руйнуванням усієї сформованої системи міжнародної наукової кооперації, оскільки саме німецькі університети відігравали ключову роль в міжнародному розподілі наукової праці.

Таким чином, можна стверджувати, що війна, перш за все, призвела до дезорганізації наукової діяльності та освітнього процесу. Був порушений звичний для університетів ритм життя, стало неможливим реалізовувати довгострокові програми. Але не тільки. Відбулася переорієнтація діяльності університетів. Перша світова війна істотно змінила світогляд університетських людей, по суті, підірвавши той університетський дух, який був вироблений зусиллями прихильників неогуманізму на етапі зародження класичного університету.

В результаті, вже в повоєнний час, продовжиться і посилиться «націоналізація» університетів, зокрема Львівського та Чернівецького. Після розпаду Австро-Угорщини і відтворення Польщі як держави в листопаді 1918 р. почалася полонізація Львівського університету, який отримав ім'я польського короля Яна Казимира. Викладання 3 цього часу велося виключно польською мовою, протягом двох-трьох років були звільнені всі викладачі-українці, а для української молоді утруднено вступ до університету. Українські студенти позбавлялися можливості продовжити навчання, будучи звинувачені в тому, що вони були ворогами незалежної Польщі. Українці оголосили бойкот Львівського університету i в 1921 р. створили свій Український таємний університет, який проіснував до 1925 р. і 
був змушений припинити існування через нестачу коштів та дискримінацію при працевлаштуванні випускників, дипломи яких не визнавалися державою.

Аналогічний процес, тільки румунізації, відбувався і в Чернівцях. Велика частина німецьких професорів відмовилася «румунізувати» свої лекції. У вересні 1919 року більш як 30 німецьких професорів назавжди залишили Чернівці. Процес «румунізації» університету тривав до 1924 р., в результаті чого багато академічних традицій було знищено, а університет втратив колишнє значення ${ }^{32}$.

Процеси «націоналізації» торкнулися також і університетів підросійської України. Так, в Києві паралельно з Університетом Св. Володимира з жовтня 1917 р. почав функціонувати Український народний університет (при гетьмані П. Скоропадському називався Київський державний український університет), який 1919 р. планувалося об'єднати 3 Університетом Св. Володимира під назвою Київський державний український університет Св. Володимира з українською мовою викладання (реалізувати цей проект Директорія Української Народної Республіки не встигла). В радянській Україні на початку 1920-х років також почнеться «українізація», проте становище університетів буде більшою мірою визначатися іншими процесами. «Старі» університети будуть оголошені не тільки знаряддям колоніального гноблення, а й «цитаделями» буржуазно-феодальних порядків. В ході так званої «реорганізації» всі вони будуть істотно перепрофільовані. По суті, вони будуть перетворені на спеціалізовані педагогічні навчальні заклади, відбудеться відділення «наукової частини» від навчальної, будуть запроваджені дискримінаційні заходи щодо складу студентів і викладачів у зв'язку з їх соціальним походженням і політичними настроями, на деякий час припинить існування система наукових ступенів, державний підхід стане панівним, в системі управління утвердиться принцип «єдиноначальності». Повоєнна історія українських університетів значною мірою співзвучна 3 тим, що спостерігалося в цей же час і в Німеччині. В цьому плані ми можемо говорити про загальні тенденції в розвитку університетів.

Так, сучасний американський дослідник Фріц Рінгер зазначає: «Посредством принципа фюрерства было уничтожено университетское самоуправление. Идеи научной свободы и объективности были официально отвергнуты. Третий рейх не нуждался в «непрактичной» учености, классическом гуманизме и «аполитичности» и не желал терпеть в университетах «академический пролетариат». Были введены квоты на поступление с особенно суровыми ограничениями для женщин. ... Наибольшие потери понесли теоретические дисциплины, такие как философия; узкопрофессиональные предметы пострадали не так сильно. Одновременно с этим у абитуриентов стали требовать сертификаты о примерном поведении и политической благонадежности. Будущие школьные учителя и университетские преподаватели обязаны были демонстрировать неразрывную связь с нацией в трудовых лагерях и на политических собраниях. Высшее образование утратило свою сугубо интеллектуальную и научную сущность» ${ }^{33}$.

Націоналізація університетів призвела до краху класичного університету. Не дивно, що найкращі німецькі університети не стали на заваді утвердженню нацизму, не стали центрами опору йому (принаймні, інтелектуальними). Зокрема, таким сумним прикладом став старіший Гейдельберзький університет - перший у Німеччині, де відкрито підтримали націонал-соціалізм. В спалюванні книг на Університетській площі навесні 1933 р. брали активну участь, насамперед, студенти та співробітники університету. Посвячення на будівлі університету «Духу живому» тоді ж було перероблено на «Духу німецькому», і багато професорів та студентів щиро служили цьому девізу. До речі, відомий міністр пропаганди Йозеф Геббельс теж був випускником цього навчального закладу. Звичайно, були й інші... Втім, невдовзі було звільнено чимало викладачів єврейського походження, а потім почалися виключення студентів та звільнення професорів 3 політичних і расистських причин. Багато хто був змушений емігрувати, деякі професори і студенти стали жертвою терору.

Все сказане можна охарактеризувати не інакше як кризу класичного університету. Кожна 3 названих вище рис класичного університету, розвиваючись, починала заперечувати саму ідею університету. Стався «розрив» в університетській історії. Втім, суцільних розривів в культурі не існує. Всі зазначені проблеми класичного університету (як і традиції та переваги) наслідував сучасний університет. 
${ }^{1}$ Moraw P. Aspekte und Dimensionen älterer deutscher Universitätsgeschichte // Academia Gissensis, hg. von P. Moraw und V. Press. Marburg, 1982. S. 1-43; Moraw P. Universitäten, Gelehrte und Gelehrsamkeit in Deutschland vor und um 1800 // Humboldt International. Der Export des deutschen Universitätsmodells im 19. und 20. Jahrhundert. Basel, 2001. S. 20.

${ }^{2}$ Hammerstein N. Aufklärung und katholisches Reich. Untersuchungen zur Universitätsreform und Politik katholischer Territorien des Heiligen Römischen Reichs deutscher Nation im 18. Jahrhundert. Berlin, 1977. S. 201.

3 Андреев А. Ю. «Гумбольдтовский миф» и дискуссии о модели классического университета в современной зарубежной историографии // Харківський історіографічний збірник. Х., 2004. Вип. 7.

${ }^{4}$ Докладніше про це див.: Андреев А. Ю. Российские университеты XVIII - первой половины XIX века в контексте университетской истории Европы. М., 2009.

5 Див.: Университетская идея в Российской империи XVIII - начала XX веков: Антология / сост. А. Ю. Андреев, С. И. Посохов. М., 2011.

${ }^{6}$ Паульсен Ф. Германские университеты. СПб., 1904. С. 242-243.

${ }^{7}$ Касьянов Г. Теорії нації та націоналізму. К., 1999. С. 210.

${ }^{8}$ Сарбей В. Г. Національне відродження України // Україна крізь віки: У 15 т. / заг. ред. В. А. Смолія. К., 1999. Т. 9. С. 48.

${ }^{9}$ Миллер А. И. «Украинский вопрос» в политике властей и русском общественном мнении (вторая половина ХІХ в.). СПб., 2000. С. 83.

10 Mаурер T. Русский Юрьевский университет и немецкий Страсбургский университет: утраченные форпосты // Университет и город в России (начало XX в.). М., 2009. С. 705.

${ }^{11}$ Докладніше про це див.: Маурер Т. «Барометры» или «маяки» общества? М., 2015. С. 284-310.

${ }_{12}$ Цит. за: Маурер T. «Барометры» или «маяки» общества? М., 2015. С. 305.

13 Эймонтова Р. Г. Русские университеты на грани двух эпох: От России крепостной к России капиталистической. М., 1985. С. 296.

${ }^{14}$ Миллер А. И. «Украинский вопрос» в политике властей... С. 147.

${ }^{15}$ Там само. С. $147-148$.

${ }^{16}$ Наумов С. О. Харківська «Вільна громада» РУП (1900-1904 рр.): до 100-річчя партії // Вісник Харківського університету. Сер. Історія. Х., 2000. Вип. 32. С. 114-115.

17 Зашкільняк Л. Михайло Грушевський і Галичина (до приїзду до Львова 1894 р.) // Михайло Грушевський і українська історична анука: зб. матер. конф. Л., 1999. С. 151.

${ }^{18}$ Грушевский М. С. Вопрос об украинских кафедрах и нужды университетской науки. СПб., 1907. С. 3; Драгоманов М. Листи на Наддніпрянську Україну // Тисяча років української суспільнополітичної думки: У 9 т. К., 2001. Т. 5. Кн. 2. С. 148.

${ }^{19}$ Програма Української партії самостійників - соціалістів (УНП) // Тисяча років української суспільно-політичної думки: У 9 т. К., 2001. Т. 6. С. 68-69.

20 Драгоманов М. П. Неправда - не просвіта // Драгоманов М. П. Літературно-публіцистичні праці: В 2 т. К., 1970. Т. 2. С. 398.

${ }_{21}$ Грушевский М. С. Вопрос об украинских кафедрах и нужды университетской науки. СПб., 1907. C. 48.

22 Mаурер T. Русский Юрьевский университет и немецкий Страсбургский университет: утраченные форпосты // Университет и город в России (начало ХХ в.). М., 2009. С. 707.

${ }^{23}$ Маурер Т. «Барометры» или «маяки» общества? М., 2015. С. 283.

${ }^{24}$ Про це див.: Ringer F. The decline of the German Mandarins. The German Academic Community, 1890-1933. Cambridge, Mass.: Harvard University Press. 1969 (в російському перекладі: Ридинг Ф. Закат немецких мандаринов: Академическое сообщество в Германии, 1890-1933 / Пер. с англ. Е. Канищевой и П. Гольдина. М., 2008).

${ }^{25}$ Див: Bakirov V., Posokhov S. Universities during World War 1: common trends and Ukrainian experience // IUIES JOURNAL (International University Institute for European Studies Journal). 2017. Vol. 4, № 1.

${ }^{26}$ Див.: Дмитриев А. Н. Мобилизация интеллекта: Международное научное сообщество и Первая мировая война// Интеллигенция в истории: Образованный человек в социальных представлениях и действительности. М., 2001. URL: http://august-1914.over.ru/dmitriev.pdf (дата звернення: 17.04.2017).

${ }^{27}$ Там само.

${ }^{28}$ Там само.

${ }^{29}$ Історія Київського університету. К., 2014. С. 182.

${ }^{30}$ Про це див.: Пиріг Р. Я., Тельвак В. В. Михайло Грушевський: біографічний нарис. К., 2017. С. 256.

31 Черказьянова И. В. Профессор П. Э.Соколовский во главе Харьковского учебного округа // Universitates $=$ Университеты. Наука и просвещение. Х., 2004. № 3. С. 69.

32 Заполовський В. Чернівецька «Франціско Йозефіна» (роки війни 1914-1918рp.) // Міні-космос Буковини. Культурні здобутки регіону: Матеріали Міжнар. наук. конф., присвяченої 130-річчю Чернівецького університету. Чернівці, 2006. С. 79.

${ }_{33}$ Рингер Ф. Закат немецких мандаринов: Академическое сообщество в Германии, 1890-1933 / Пер. с англ. Е. Канищевой и П. Гольдина. М., 2008. С. 526-527. 